\title{
Pharmacy Customers' Experiences With Electronic Prescriptions: Cross-Sectional Survey on Nationwide Implementation in Finland
}

Elina Lämsä, MSc (Pharm); Johanna Timonen, PhD (Pharm); Riitta Ahonen, PhD (Pharm)

School of Pharmacy, Faculty of Health Sciences, University of Eastern Finland, Kuopio, Finland

Corresponding Author:

Elina Lämsä, MSc (Pharm)

School of Pharmacy

Faculty of Health Sciences

University of Eastern Finland

PO Box 1627

Kuopio, 70211

Finland

Phone: 358403552041

Email: elina.lamsa@uef.fi

\section{Abstract}

Background: One of the forerunners in electronic health, Finland has introduced electronic prescriptions (ePrescriptions) nationwide by law. This has led to significant changes for pharmacy customers. Despite the worldwide ambition to develop ePrescription services, there are few reports of nationally adopted systems and particularly on the experiences of pharmacy customers.

Objective: The aim of this study was to investigate Finnish pharmacy customers' (1) experiences with purchasing medicines with ePrescriptions; (2) experiences with renewing ePrescriptions and acting on behalf of someone else at the pharmacy; (3) ways in which customers keep up to date with their ePrescriptions; and (4) overall satisfaction with ePrescriptions.

Methods: Questionnaires were distributed to 2913 pharmacy customers aged $\geq 18$ years purchasing prescription medicines for themselves with an ePrescription in 18 community pharmacies across Finland in autumn 2015. Customers' experiences were explored with 10 structured questions. The data were stored in SPSS for Windows and subjected to descriptive analysis, chi-square, Fisher exact, Kolmogorov-Smirnov, the Mann-Whitney U, and Kruskal-Wallis tests.

Results: Completed questionnaires were returned by 1288 customers, a response rate of 44.19\% (1288/2913). The majority of the respondents did not encounter any problems during pharmacy visits $(1161 / 1278,90.85 \%)$ and were informed about the current status of their ePrescriptions after their medication was dispensed (1013/1276, 79.44\%). Over half of the respondents had usually received a patient instruction sheet from their physician $(752 / 1255,59.92 \%)$, and nearly all of them regarded its content as clear $(711 / 724,98.2 \%)$. Half of the respondents had renewed their ePrescriptions through the pharmacy $(645 / 1281,50.35 \%)$, and one-third of them had acted on behalf of someone else with ePrescriptions (432/1280, 33.75\%). Problems were rarely encountered in the renewal process $(49 / 628,7.8 \%)$ or when acting on behalf of another person $(25 / 418,6.0 \%)$ at the pharmacy. The most common way of keeping up to date with ePrescriptions was to ask at the pharmacy $(631 / 1278,49.37 \%)$. The vast majority of the respondents were satisfied with ePrescriptions as a whole $(1221 / 1274,95.84 \%)$.

Conclusions: Finnish pharmacy customers are satisfied with the recently implemented nationwide ePrescription system. They seldom have any difficulties purchasing medicines, renewing their ePrescriptions, or acting on behalf of someone else at the pharmacy. Customers usually keep up to date with their ePrescriptions by asking at the pharmacy. However, some customers are unaware of the practices or have difficulty keeping up to date with the status of their ePrescriptions. The provision of relevant information and assistance by health care professionals is therefore required to promote customers' adoption of the ePrescription system.

(J Med Internet Res 2018;20(2):e68) doi: 10.2196/jmir.9367

\section{KEYWORDS}

electronic prescribing; pharmacies; patient satisfaction; surveys and questionnaires 


\section{Introduction}

\section{Introduction of ePrescriptions}

Electronic health (eHealth), including electronic health records, electronic identification, online portals, and mobile health apps, has rapidly become common not only among health care providers but also patients and consumers. eHealth is about efficient and high-quality services, empowerment of patients, as well as enhanced information exchange and communication between health care professionals and patients [1]. As part of eHealth strategies, the implementation of electronic prescriptions (ePrescriptions) has been assessed as a pharmaceutical policy reform in many countries [2-4]. For example, in 2017, the Government of Canada invested Can $\$ 300$ million over 5 years to enhance eHealth activities, including expanding ePrescribing and patients' access to their electronic health records [5]. The implementation of ePrescriptions primarily aims not just to improve medication safety but also to enhance the prescribing, dispensing, and purchasing of medicines [2,6]. The definition of ePrescription, however, varies between electronic transfer of a prescription from a prescriber to a particular pharmacy and a nationwide system where prescriptions are issued, transferred, stored, dispensed, and renewed via an information network $[2,4,6]$. This latter system has so far been introduced in a few countries including Sweden, Estonia, Denmark, the Netherlands, and Finland.

Once introduced, health care policy reforms should be rigorously evaluated by comparing their actual impacts with those anticipated before implementation $[7,8]$. The evaluation should encompass the effects from different viewpoints. The implementation of ePrescriptions has been widely studied from the perspective of health care professionals. Studies have concerned topics such as the benefits and problems of ePrescriptions [9-11], facilitators and barriers to their implementation [12], and their impact on workflow and medication safety [11,13-15]. However, experiences from nationwide ePrescription systems have been reported in only a few studies [7,9,14-17].

\section{Patients' Perceptions of ePrescriptions}

Despite researchers' wide interest in the implementation of ePrescriptions, the literature on the experiences of patients-one of the main user groups-is limited. The aim of ePrescriptions is to offer enhanced health care for patients. They enable the electronic storing of prescriptions and, as a consequence, streamline the purchasing of medicines at the pharmacy or even online [17]. Furthermore, electronic storing of medical records has provided patients with access to their personal records via Web-based services, and this has given them a more active role in the management of their medications [18-20]. It is therefore important to study whether patients have sufficient understanding of the system, whether they know how to use the services, and whether the services operate properly [21].

Patients' perceptions of ePrescriptions have been studied in the United States [22-26] and Sweden [17]. Studies conducted in Australia [27] and Scotland [28] have reported patients' attitudes toward ePrescriptions before the implementation. However, the study settings have mainly been local and the samples rather small, involving patients from 1 clinic [23,24,27] or 1 state $[25,26]$. According to the literature, patients' attitudes toward ePrescriptions are positive $[17,22,23,27,28]$ partly as a result of their experiences with ePrescription services [17,22]. An ePrescription has commonly been defined as a prescription that a prescriber electronically issues and sends to a certain pharmacy [22-27]. To the authors' knowledge, patients' attitudes toward a nationwide ePrescription system have only been studied in Sweden [17]. However, there is little published information on how the nationwide system works in practice from the patient's perspective and how patients keep up to date with their ePrescriptions.

This study is part of a research project studying health care professionals' and patients' experiences with the recently implemented nationwide ePrescription system in Finland. The project aims to investigate whether the system has achieved the objectives predefined by law. The objective of this study was to investigate Finnish pharmacy customers' experiences with ePrescriptions. The specific aims were to explore the following:

- $\quad$ experiences of purchasing medicines with ePrescriptions

- experiences of renewing ePrescriptions and acting on behalf of someone else at the pharmacy

- how customers keep up to date with their ePrescriptions

- how satisfied they are with the ePrescription system as a whole

\section{Methods}

\section{Study Context}

\section{Introduction of ePrescriptions in Finland}

In Finland, the nationwide introduction of ePrescriptions by law began in 2012, and Finnish pharmacies started to dispense ePrescriptions in the same year [29]. The issuing of ePrescriptions was made obligatory in public health care in 2013 and in private health care in 2015 . At the beginning of 2017, all health care providers were obliged to introduce the ePrescription system, and nowadays, conventional prescriptions (eg, paper, telephone) are only permitted in exceptional situations such as blackouts. The use of ePrescriptions aims to improve patient and medication safety as well as facilitate and streamline the prescribing and dispensing of medicines. In 2015, when the survey reported in this paper was conducted, over $90 \%$ of nearly 56 million prescriptions dispensed in Finnish pharmacies were electronic [30,31].

\section{The ePrescription System From the Patient's Perspective}

In Finland, ePrescriptions are issued, transferred, stored, and dispensed electronically [29]. Once issued, ePrescriptions are stored in a centralized database (the Prescription Centre) from which they can be retrieved and dispensed in any Finnish pharmacy. The patient can choose the most convenient pharmacy at the time of purchasing the medicine. Patients can view their ePrescriptions and other personal medical records in a Web service called My Kanta [19,32].

A patient who is present when an ePrescription is issued is entitled to receive a patient instruction sheet from the physician. The document includes a summary of the ePrescription: the 
brand or generic name of the medicine prescribed, dosage instructions, prescriber, place and date of prescribing, quantity or duration of therapy, and the expiry date of the prescription. However, the patient can decline to receive a patient instruction sheet.

At the pharmacy, a patient gets his or her medicines dispensed by showing a patient instruction sheet, a personal health insurance card, or other valid ID [33]. The Act on Electronic Prescriptions 61/2007 requires the pharmacist to give the patient the latest information about the amount of medication still to be dispensed. The information is also printed out onto the dispensing label to be attached to the medicine package.

The patient can ask for a renewal of an ePrescription at a health care unit or at a pharmacy from where the renewal request is sent electronically to a health care unit [33]. Patients can ask someone else to act on their behalf at the pharmacy. The person purchasing another's medicine with an ePrescription is required to present the patient's insurance card or a patient instruction sheet. Signed consent is needed when a patient authorizes another person to ask for a renewal of an ePrescription, requests a printed summary of his or her ePrescriptions, or asks the pharmacist, physician, or nurse to delete his or her ePrescription.

\section{Validity of Prescriptions}

In Finland, a prescription is valid for 2 years from the date of issue, the exceptions being prescriptions for central nervous system agents with abuse potential or narcotic agents, which are valid for 12 months. Prescription validity was extended from 12 months to 24 months in January 2017; so, at the time of this study, ePrescriptions were valid for 1 year. A prescription can be prescribed for a specific period (1-year dosage) or for an amount (400 tablets). Nevertheless, patients can be reimbursed for the maximum of 3 months' dosage dispensed at the pharmacy at a time. Consequently, a reimbursable purchase for 3 months' medication can be repeated 4 times during the validity period of 1 year.

\section{The Survey}

A questionnaire survey was conducted among pharmacy customers aged $\geq 18$ years who were purchasing medicines for themselves with ePrescriptions in autumn 2015. Questionnaires were handed out by 18 different-sized pharmacies across Finland. The number of questionnaires delivered to each pharmacy varied between 30 and 200, and was adjusted according to the number of prescriptions dispensed daily at the pharmacy. We provided pharmaceutical staff with instructions on the distribution of questionnaires. Pharmacists informed customers about the study after dispensing their medication and offered them the questionnaire together with a franked envelope for their responses. They were not required to keep a list of customers who declined to participate. The questionnaires were handed out as long as there were forms left, but for a maximum of 2 weeks. After the study period, pharmacies reported the number of questionnaires left to compute the response rate. Altogether, 2915 questionnaires were distributed. Reminders could not be sent as we were unaware of the customers' addresses.

\section{The Questionnaire}

The 4-page form contained 26 questions (Multimedia Appendix 1). The main themes of the questions were as follows: (1) customers' experiences with purchasing medicines with ePrescriptions, (2) experiences with and opinions on the My Kanta service, (3) opinions on the benefits and problems with ePrescriptions, and (4) information sources and information needs related to ePrescriptions. The questionnaire was designed on the basis of the mandated objectives of ePrescriptions [29], the anticipated impacts of ePrescriptions [34], and some previous studies $[17,35]$. The questionnaire was pilot tested in a local pharmacy in spring 2015. The pilot customers were interviewed at the pharmacy after filling in the questionnaires to check that they had understood the questions. Minor modifications were made based on the pilot test. However, modifying the questions reported in this paper was not necessary.

This paper reports results from 10 questions related to respondents' experiences with purchasing medicines with ePrescriptions, renewing ePrescriptions through the pharmacy, acting on behalf of another person, and their overall satisfaction with ePrescriptions (Questions 2-10 and 21 in Multimedia Appendix 1). Two questions were defined with the phrase "this time at the pharmacy," the aim being to gain cross-sectional data about technical problems or ambiguities in ePrescriptions during the dispensing process and how pharmacists comply with the instruction to inform customers about their ePrescription details. All the questions were structured. Some questions had space for respondents to expand on their answer, and some were multiple choice questions. The question asking how satisfied the respondent is with ePrescriptions as a whole was answered on a 6-point Likert-type rating scale, where 1 represented not at all satisfied and 6 very satisfied.

Structured questions yielded background information on the respondents' gender, area of residence, education, and regularity of prescription medicine use (Questions 22 and 24-26 in Multimedia Appendix 1). The respondent's year of birth was obtained by means of an open-ended question (Question 23 in Multimedia Appendix 1). Furthermore, to explore the extent of respondents' experiences, a structured question asked respondents to estimate how many times they had purchased medicines with ePrescriptions within the last 6 months (Question 1 in Multimedia Appendix 1).

\section{Statistical Methods}

Data from the questionnaires were entered into the Statistical Package for Social Scientists software (version 23.0 SPSS Inc, Chicago, IL, USA). A descriptive approach (frequencies, means) was used in the analysis. In the analyses, the respondent's age was placed into 1 of the 4 groups (18-34, 35-59, 60-74, and 75 years or older). Categorical data from questions concerning respondents' experiences with ePrescriptions, renewals at the pharmacy, acting on behalf of someone else, and checking the status of ePrescription were compared with background variables using either the Pearson chi-square test or two-sided Fisher exact test. After Kolmogorov-Smirnov normality test, statistical significance of differences between means in independent groups was assessed using the Mann-Whitney $U$ or Kruskal-Wallis 
tests for the satisfaction with ePrescriptions. Statistical significance was determined as $P<.05$.

\section{Ethical Statement}

The study setting and research process complied with local and national ethical instructions for research [36]. This study required no ethical approval.

\section{Results}

\section{Study Population}

In total, 2915 questionnaires were handed out to pharmacy customers and 1290 were returned to the authors. Two forms, however, were excluded as the respondents were aged less than 18 years. Consequently, the study sample was 2913, giving a response rate of $44.21 \%(\mathrm{~N}=1288)$.

Background information on the study population is presented in Table 1.

Table 1. Characteristics of the study respondents $(\mathrm{N}=1288)$.

\begin{tabular}{|c|c|}
\hline Characteristic & $\mathrm{n}(\%)$ \\
\hline \multicolumn{2}{|l|}{ Gender $\left(n=1287^{a}\right)$} \\
\hline Female & 965 (74.98) \\
\hline Male & $322(25.02)$ \\
\hline \multicolumn{2}{|l|}{ Age in years $\left(n=1167^{a}\right)$} \\
\hline $18-34$ & $137(11.74)$ \\
\hline $35-59$ & $379(32.48)$ \\
\hline $60-74$ & $476(40.79)$ \\
\hline$\geq 75$ & $175(15.00)$ \\
\hline \multicolumn{2}{|l|}{ Education $\left(n=1263^{a}\right)$} \\
\hline Basic education (comprehensive school) & $274(21.69)$ \\
\hline Vocational degree & $459(36.34)$ \\
\hline Secondary school graduate & $152(12.03)$ \\
\hline Lower-level university degree & $203(16.07)$ \\
\hline Higher-level university degree & $175(13.86)$ \\
\hline \multicolumn{2}{|c|}{ Current use of prescription medicines $\left(n=1272^{a}\right)$} \\
\hline Temporarily & $117(9.20)$ \\
\hline Regularly & $715(56.21)$ \\
\hline Both regularly and temporarily & $440(34.59)$ \\
\hline \multicolumn{2}{|l|}{ Area of residence $\left(n=1276^{a}\right)$} \\
\hline Southern Finland & $301(23.59)$ \\
\hline Southwestern Finland & $208(16.30)$ \\
\hline Western and Central Finland & $205(16.07)$ \\
\hline Eastern Finland & $183(14.34)$ \\
\hline Northern Finland & $256(20.06)$ \\
\hline Lapland & $123(9.64)$ \\
\hline \multicolumn{2}{|c|}{ Medicine purchases with an ePrescription within the last six months $\left(N=1283^{a}\right)$} \\
\hline First time during the study & $37(2.88)$ \\
\hline $2-5$ times & $688(53.62)$ \\
\hline 6-10 times & $335(26.11)$ \\
\hline Over 10 times & $223(17.38)$ \\
\hline
\end{tabular}

${ }^{\mathrm{a}}$ Some of the respondents did not report their gender, age, education, usage of prescription medicines, area of residence, or how many times they had purchased medicines with an ePrescriptions within the last 6 months. 
The majority of the respondents were female and the mean age was 59 years (range 18-93, median 62). All 6 geographical areas of Finland were represented among the study population. Most of the respondents had gained experience with purchasing medicines with ePrescriptions several times within the previous 6 months.

\section{Experiences With the Patient Instruction Sheet}

Over half $(752 / 1255,59.92 \%)$ of the respondents had usually received a patient information sheet concerning the prescribed medicine from the physician (Table 2). Over one-third of the respondents $(503 / 1255,40.08 \%)$ reported not receiving the information sheet: for $23.75 \%(298 / 1255)$, the physician did not offer it, whereas $5.58 \%$ (70/1255) reported they had declined to receive it. The rest $(135 / 1255,10.76 \%)$ did not know what a patient information sheet is. Those who had usually received the sheet generally regarded its content as clear (711/724, $98.2 \%)$. However, respondents in the age group 75 years and older were likely to state that the content was unclear $(P=.04)$.

\section{Experiences With Purchasing Medicines With ePrescriptions}

The majority $(1161 / 1278,90.85 \%)$ of the respondents reported not encountering any problems with their ePrescriptions at the pharmacy (Table 2). Almost one-tenth (117/1278), however, experienced some inconvenience or a problem during the visit.

From the total of 162 reported problems, the most common were that the ePrescription had expired without the respondent's knowledge (59/117, 50.4\%), the ePrescription had no medication remaining and the respondent was unaware of this (40/117, $34.2 \%$ ), and the physician had not sent the ePrescription as promised $(22 / 117,18.8 \%)$. Those aged 75 years and older and respondents using prescription medicines both regularly and temporarily were more likely to experience problems $(P=.005$ and $P=.04$, respectively) compared with others (Table 2 ).

Most of the respondents (1013/1276, 79.29\%) were told how much medication was remaining on their ePrescription after the purchase (Table 2). Older pharmacy customers were more likely to be informed about the number of batches remaining than working age customers $(P<.001)$. Furthermore, significant differences were observed between respondents' education level $(P=.02)$ and the regularity of prescription medicine use $(P<.001)$. Those with higher levels of education and those using prescription medicines only temporarily were unlikely to be informed compared with respondents with only basic education or using prescription medicines regularly.

\section{Experiences With ePrescription Renewals and Acting on Behalf of Someone Else}

Approximately half of the respondents $(645 / 1281,50.35 \%)$ had renewed their ePrescriptions through the pharmacy (Table 2).
Significant differences were observed between genders $(P=.033)$, age groups $(P<.001)$, education $(P<.001)$, regularity of prescription medicine use $(P<.001)$, and area of residence $(P<.001)$. Those who had made the renewal request at the pharmacy rarely encountered any problems during the process $(579 / 628,92.2 \%)$. However, 49 respondents $(7.8 \%)$ reported inconveniences such as long waiting times, medication running out before the renewal, technical problems, no notification that a renewal had been authorized or that the ePrescription had not been renewed despite the customer's request.

One-third of the respondents (432/1280, 33.75\%) had acted on behalf of someone else with an ePrescription at the pharmacy. The majority of those who had acted on behalf of others were satisfied with the service $(393 / 418,94.1 \%)$, whereas 25 respondents $(6 \%)$ reported problems such as being unaware of the required signed consent or a parent's inability to access a minor's up-to-date ePrescription details in the My Kanta service.

\section{Experiences With Keeping Up to Date With ePrescriptions}

The respondents generally kept up to date with their ePrescription status (eg, amount of medication remaining or expiry date of a prescription) by asking at the pharmacy $(631 / 1278,49.37 \%)$, reading the label affixed to the medication package $(574 / 1278,44.91 \%)$, or using the My Kanta Web service $(491 / 1278,38.42 \%)$; see Table 3.

Asking at the pharmacy and reading the dispensing label were the most common methods among the oldest age group $(P=.01$ and $P<.001$, respectively). In contrast, the oldest pharmacy customers were less likely to use My Kanta than younger respondents $(P<.001)$.

Reading the dispensing label was also common among women $(P=.008)$, respondents using prescription medicines regularly $(P<.001)$, and respondents with only basic education $(P<.001)$. The My Kanta service was used regularly by respondents with education higher than comprehensive school $(P<.001)$ and by those using prescription medicines both regularly and temporarily $(P=.03)$.

\section{Overall Satisfaction With ePrescriptions}

The general attitude toward ePrescriptions was positive among the respondents. On the 6-point Likert scale, 95.84\% $(1221 / 1274)$ of all respondents rated their overall satisfaction as 4 to 6 (Table 4). The mean for the level of satisfaction was 5.35. Overall satisfaction differed significantly between age groups $(P=.049)$, respondents' education $(P<.001)$, and regularity of prescription medicine use $(P=.03)$. The oldest respondents, respondents with only basic education, and respondents using prescription medicines regularly were likely to be very satisfied with ePrescriptions. 
Table 2. Respondents' experiences with ePrescriptions.

\begin{tabular}{|c|c|c|c|c|c|}
\hline Characteristic & $\begin{array}{l}\text { Has usually re- } \\
\text { ceived a patient } \\
\text { instruction sheet } \\
\text { from a physician }\end{array}$ & $\begin{array}{l}\text { Perceives the } \\
\text { content of the pa- } \\
\text { tient instruction } \\
\text { sheet as clear }\end{array}$ & $\begin{array}{l}\text { Did not encounter any } \\
\text { problems with his or } \\
\text { her ePrescription(s) at } \\
\text { the pharmacy }\end{array}$ & $\begin{array}{l}\text { Was told about the } \\
\text { amount of medication } \\
\text { still to be dispensed un- } \\
\text { der the ePrescription(s) } \\
\text { at the pharmacy }\end{array}$ & $\begin{array}{l}\text { Has renewed } \\
\text { ePrescription(s) } \\
\text { through the } \\
\text { pharmacy }\end{array}$ \\
\hline All, n (\%) & $752(59.92)$ & $711(98.20)$ & $1161(90.85)$ & 1013 (79.39) & $645(50.35)$ \\
\hline Gender & $P=.42$ & $P=.74$ & $P=.47$ & $P=.10$ & $P=.03$ \\
\hline Female, n (\%) & $571(60.6)$ & $542(98.0)$ & $867(90.5)$ & $751(78.3)$ & $466(48.6)$ \\
\hline Male, n (\%) & $181(58.0)$ & $169(98.8)$ & $293(91.8)$ & $261(82.6)$ & $178(55.5)$ \\
\hline Age in years & $P=.545$ & $P=.039$ & $P=.005$ & $P<.001$ & $P<.001$ \\
\hline $18-34, \mathrm{n}(\%)$ & $77(56.2)$ & $71(97)$ & $127(92.7)$ & $96(70.1)$ & $30(21.9)$ \\
\hline $35-59, \mathrm{n}(\%)$ & $224(59.3)$ & $215(99.1)$ & $354(93.7)$ & $274(73.3)$ & $144(38.2)$ \\
\hline $60-74, \mathrm{n}(\%)$ & $283(61.8)$ & $271(98.9)$ & $425(90.0)$ & $397(84.5)$ & $282(59.6)$ \\
\hline$\geq 75, \mathrm{n}(\%)$ & $96(56.8)$ & $86(95)$ & $146(84.4)$ & $150(85.7)$ & $132(75.9)$ \\
\hline Education & $P=.73$ & $P=.06$ & $P=.20$ & $P=.02$ & $P<.001$ \\
\hline Basic education, $\mathrm{n}(\%)$ & $151(59.5)$ & $144(99.3)$ & $238(87.5)$ & $229(85.1)$ & $182(67.4)$ \\
\hline Vocational degree, $\mathrm{n}(\%)$ & $277(61.4)$ & $265(99.3)$ & $415(91.0)$ & $365(80.2)$ & $251(54.9)$ \\
\hline Secondary school graduate, n (\%) & $94(62.7)$ & $90(99)$ & $142(93.4)$ & $117(77.0)$ & $56(36.8)$ \\
\hline Lower-level university degree, n (\%) & $117(57.9)$ & $106(95.5)$ & $182(91.0)$ & $147(72.8)$ & $73(36.1)$ \\
\hline Higher-level university degree, n (\%) & $98(56.6)$ & $94(96.9)$ & $163(93.1)$ & $133(76.9)$ & $65(37.1)$ \\
\hline Current use of prescription medicines & $P=.16$ & $P=.13$ & $P=.04$ & $P<.001$ & $P<.001$ \\
\hline Temporarily, n (\%) & $69(59.0)$ & $68(100)$ & $111(94.9)$ & $74(64.3)$ & $30(25.6)$ \\
\hline Regularly, n (\%) & $399(57.9)$ & $377(99.0)$ & $650(91.9)$ & $570(80.6)$ & $376(52.7)$ \\
\hline Both regularly and temporarily, n (\%) & $278(63.6)$ & $261(97.0)$ & $387(88.4)$ & $354(80.8)$ & $228(52.3)$ \\
\hline Area of residence & $P=.07$ & $P=.56$ & $P=.17$ & $P=.29$ & $P<.001$ \\
\hline Southern Finland, n (\%) & $174(59.6)$ & $161(97.0)$ & $275(91.7)$ & $232(77.6)$ & $110(36.8)$ \\
\hline Southwestern Finland, n (\%) & $132(64.1)$ & $122(98.4)$ & $193(92.8)$ & $153(74.3)$ & $94(45.4)$ \\
\hline Western and Central Finland, n (\%) & $135(67.5)$ & $129(98.5)$ & $183(91.0)$ & $164(80.8)$ & $107(52.7)$ \\
\hline Eastern Finland, n (\%) & $100(56.2)$ & $94(96.9)$ & $162(89.5)$ & $145(79.7)$ & $115(63.2)$ \\
\hline Northern Finland, n (\%) & $136(54.6)$ & $131(99.2)$ & $223(87.5)$ & $208(82.2)$ & $130(51.0)$ \\
\hline Lapland, n (\%) & $70(58.3)$ & $69(100)$ & $115(95.0)$ & $101(82.8)$ & $80(65.0)$ \\
\hline
\end{tabular}

${ }^{\mathrm{a}}$ Respondents who had usually received a patient information sheet answered the question. 
Table 3. How respondents $(\mathrm{N}=1278)$ check the status of their ePrescriptions (eg, amount of medication remaining or expiry date of a prescription). A respondent may have chosen several alternatives.

\begin{tabular}{|c|c|c|c|c|c|c|c|}
\hline Characteristic & $\begin{array}{l}\text { Ask at the } \\
\text { pharmacy }\end{array}$ & $\begin{array}{l}\text { Read the label } \\
\text { affixed to the } \\
\text { medication } \\
\text { package }\end{array}$ & $\begin{array}{l}\text { Use the My } \\
\text { Kanta service }\end{array}$ & $\begin{array}{l}\text { Keep track of } \\
\text { it themselves }\end{array}$ & $\begin{array}{l}\text { Read the patient } \\
\text { instruction } \\
\text { sheet }\end{array}$ & $\begin{array}{l}\text { Do not check } \\
\text { it at all }\end{array}$ & $\begin{array}{l}\text { Use another } \\
\text { method }^{\text {a }}\end{array}$ \\
\hline All, n (\%) & $631(49.37)$ & $574(44.91)$ & $491(38.42)$ & $109(8.53)$ & $72(5.63)$ & $65(5.09)$ & $25(1.96)$ \\
\hline Gender & $P=.13$ & $P=.008$ & $P=.42$ & $P=.32$ & $P=.40$ & $P>.99$ & $P=.13$ \\
\hline Male, n (\%) & $146(45.3)$ & $123(38.2)$ & $129(40.1)$ & $23(7.1)$ & $15(4.7)$ & $16(5.0)$ & $3(0.9)$ \\
\hline Age in years & $P=.01$ & $P<.001$ & $P<.001$ & $P=.97$ & $P=.02$ & $P=.002$ & $P=.40$ \\
\hline $18-34, \mathrm{n}(\%)$ & $75(54.7)$ & $50(36.5)$ & $65(47.4)$ & $11(8.0)$ & $10(7.3)$ & $13(9.5)$ & $5(3.6)$ \\
\hline $35-59, \mathrm{n}(\%)$ & $187(49.3)$ & $140(36.9)$ & $180(47.5)$ & $29(7.7)$ & $23(6.1)$ & $26(6.9)$ & $6(1.6)$ \\
\hline$\geq 75, \mathrm{n}(\%)$ & $98(56.0)$ & $98(56.0)$ & $26(14.9)$ & $13(7.4)$ & $15(8.6)$ & $4(2.3)$ & $2(1.1)$ \\
\hline Education & $P=.24$ & $P<.001$ & $P<.001$ & $P=.047$ & $P=.04$ & $P<.001$ & $P=.31$ \\
\hline Basic education, n (\%) & $130(47.4)$ & $147(53.6)$ & $68(24.8)$ & $20(7.3)$ & $8(2.9)$ & $10(3.6)$ & $5(1.8)$ \\
\hline Vocational degree, n (\%) & $221(48.1)$ & $221(48.1)$ & $187(40.7)$ & $34(7.4)$ & $22(4.8)$ & $17(3.7)$ & $7(1.5)$ \\
\hline $\begin{array}{l}\text { Secondary school } \\
\text { graduate, } \mathrm{n}(\%)\end{array}$ & $81(53.3)$ & $67(44.1)$ & $62(40.8)$ & $23(15.1)$ & $11(7.2)$ & $3(2.0)$ & $1(0.7)$ \\
\hline $\begin{array}{l}\text { Lower-level university } \\
\text { degree, n }(\%)\end{array}$ & $110(54.2)$ & $69(34.0)$ & $94(46.3)$ & $17(8.4)$ & $14(6.9)$ & $14(6.9)$ & $6(3.0)$ \\
\hline $\begin{array}{l}\text { Higher-level university } \\
\text { degree, n }(\%)\end{array}$ & $77(44.0)$ & $56(32.0)$ & $72(41.1)$ & $15(8.6)$ & $16(9.1)$ & $21(12.0)$ & $6(3.4)$ \\
\hline Temporarily, n (\%) & $51(43.6)$ & $34(29.1)$ & $40(34.2)$ & $12(10.3)$ & $12(10.3)$ & $22(18.8)$ & $2(1.7)$ \\
\hline Regularly, n (\%) & $337(47.1)$ & $317(44.3)$ & $257(35.9)$ & $58(8.1)$ & $23(3.2)$ & $31(4.3)$ & $10(1.4)$ \\
\hline $\begin{array}{l}\text { Both regularly and } \\
\text { temporarily, n (\%) }\end{array}$ & $234(53.2)$ & $217(49.3)$ & $191(43.4)$ & $37(8.4)$ & $37(8.4)$ & $11(2.5)$ & $13(3.0)$ \\
\hline Area of residence & $P=.20$ & $P=.69$ & $P=.97$ & $P=.10$ & $P=.07$ & $P=.72$ & $P=.26$ \\
\hline Southern Finland, n (\%) & $142(47.2)$ & $130(43.2)$ & $118(39.2)$ & $23(7.6)$ & $18(6.0)$ & $16(5.3)$ & $9(3.0)$ \\
\hline Southwestern & $93(44.7)$ & $91(43.8)$ & $80(38.5)$ & $24(11.5)$ & $20(9.6)$ & $12(5.8)$ & $3(1.4)$ \\
\hline \multicolumn{8}{|l|}{ Finland, n (\%) } \\
\hline $\begin{array}{l}\text { Western and Central } \\
\text { Finland, n }(\%)\end{array}$ & $92(44.9)$ & $100(48.8)$ & 75 (36.6) & $17(8.3)$ & $12(5.9)$ & $10(4.9)$ & $4(2.0)$ \\
\hline Eastern Finland, n (\%) & $101(55.2)$ & $86(47.0)$ & $69(37.7)$ & $11(6.0)$ & $6(3.3)$ & $7(3.8)$ & $4(2.2)$ \\
\hline Northern Finland, n (\%) & $133(52.0)$ & $107(41.8)$ & $103(40.2)$ & $28(10.9)$ & $9(3.5)$ & $10(3.9)$ & $1(.4)$ \\
\hline Lapland, n (\%) & $63(51.2)$ & $53(43.1)$ & $45(36.6)$ & $5(4.1)$ & $7(5.7)$ & $9(5.0)$ & $3(2.4)$ \\
\hline
\end{tabular}

aFreely worded answers included "ask the physician about it," "use a Web portal of a private health center," and "monitor the consumption of the medication." 
Table 4. Respondents' (N=1274) overall satisfaction with ePrescriptions on a 6-point Likert scale, from 1 being "not at all satisfied" to 6 being "very satisfied."

\begin{tabular}{|c|c|c|c|c|c|c|c|}
\hline Characteristic & $1, \mathrm{n}(\%)$ & $2, \mathrm{n}(\%)$ & $3, \mathrm{n}(\%)$ & $4, \mathrm{n}(\%)$ & $5, \mathrm{n}(\%)$ & $6, \mathrm{n}(\%)$ & $P$ value \\
\hline All & $13(1.0)$ & $12(0.9)$ & $28(2.2)$ & $89(7.0)$ & $447(35.1)$ & $685(53.8)$ & \\
\hline Gender & & & & & & & .55 \\
\hline Female & $10(1.0)$ & $5(1.6)$ & $2(0.6)$ & $24(7.6)$ & $107(34.0)$ & $174(55.2)$ & \\
\hline Male & $3(1.0)$ & $7(0.7)$ & $26(2.7)$ & $65(6.8)$ & $339(35.4)$ & $511(53.3)$ & \\
\hline Age in years & & & & & & & .049 \\
\hline $18-34$ & $0(0.0)$ & $1(0.7)$ & $4(2.9)$ & $8(5.9)$ & $60(44.1)$ & $63(46.3)$ & \\
\hline $35-59$ & $2(0.5)$ & $3(0.8)$ & $4(1.1)$ & $23(6.1)$ & $157(41.8)$ & $187(49.7)$ & \\
\hline $60-74$ & $4(0.8)$ & $4(0.8)$ & $11(2.3)$ & $41(8.7)$ & $138(29.2)$ & $275(58.1)$ & \\
\hline$\geq 75$ & $6(3.6)$ & $3(1.8)$ & $4(2.4)$ & $5(3.0)$ & 45 (26.6) & $106(62.7)$ & \\
\hline Education & & & & & & & $<.001$ \\
\hline Basic education & $6(2.2)$ & $1(0.4)$ & $6(2.2)$ & $14(5.2)$ & $63(23.5)$ & $178(66.4)$ & \\
\hline Vocational degree & $4(0.9)$ & $7(1.5)$ & $10(2.2)$ & $36(7.9)$ & $154(33.8)$ & $244(53.6)$ & \\
\hline Secondary school graduate & $1(0.7)$ & $0(0)$ & $5(3.3)$ & $15(10.0)$ & $60(40.0)$ & $69(46.0)$ & \\
\hline Lower-level university degree & $1(0.5)$ & $2(1.0)$ & $4(2.0)$ & $4(2.0)$ & $86(42.6)$ & $105(52.0)$ & \\
\hline Higher-level university degree & $1(0.6)$ & $1(0.6)$ & $2(1.1)$ & $18(10.3)$ & $79(45.1)$ & $74(42.3)$ & \\
\hline Current use of prescription medicines & & & & & & & .03 \\
\hline Temporarily & $0(0)$ & $1(0.9)$ & $3(2.6)$ & $11(9.4)$ & $47(40.2)$ & $55(47.0)$ & \\
\hline Regularly & $8(1.1)$ & $3(0.4)$ & $11(1.6)$ & $43(6.3)$ & $240(34.0)$ & $400(56.7)$ & \\
\hline Both regularly and temporarily & $5(1.1)$ & $7(1.6)$ & $11(2.5)$ & $35(8.0)$ & $156(35.8)$ & $222(50.9)$ & \\
\hline Area of residence & & & & & & & .73 \\
\hline Southern Finland & $4(1.3)$ & $4(1.3)$ & $7(2.3)$ & $26(8.7)$ & $95(31.9)$ & $162(54.4)$ & \\
\hline Southwestern Finland & $0(0)$ & $1(0.5)$ & $5(2.4)$ & $16(7.7)$ & $86(41.5)$ & $99(47.8)$ & \\
\hline Western and Central Finland & $2(1.0)$ & $3(1.5)$ & $6(3.0)$ & $10(5.0)$ & $69(34.5)$ & $110(55.0)$ & \\
\hline Eastern Finland & $2(1.1)$ & $1(0.5)$ & $2(1.1)$ & $10(5.5)$ & $67(36.8)$ & $100(54.9)$ & \\
\hline Northern Finland & $2(0.8)$ & $2(0.8)$ & $7(2.8)$ & $14(5.5)$ & $88(34.8)$ & $140(55.3)$ & \\
\hline Lapland & $2(1.6)$ & $1(0.8)$ & $1(0.8)$ & $12(9.8)$ & $41(33.6)$ & $65(53.3)$ & \\
\hline
\end{tabular}

\section{Discussion}

\section{Principal Findings and Comparison With Prior Work}

This study found that Finnish pharmacy customers are highly satisfied with ePrescriptions as a whole. They rarely encounter any problems in purchasing medicines with ePrescriptions, in acting on behalf of someone else, or in renewing ePrescriptions at the pharmacy. The most common way of keeping up to date with their ePrescriptions is to ask at the pharmacy. The results are in line both with the literature [17,23,26] and with our earlier studies $[19,37]$.

Finnish pharmacy customers are very satisfied with the nationwide ePrescription system, even more than the Swedes [17] or pharmacists and physicians in Finland [14,15]. In our earlier study, pharmacy customers reported benefits more often than problems in ePrescriptions [37]. Overall, the most common benefits of using ePrescriptions highlighted by medicine users are the ease of purchasing prescription medicines and the electronic storing of prescriptions [17,22,23,37].
Despite its several benefits, Finnish health care professionals have criticized the ePrescription system as slow and rigid $[14,15]$. Although the new system has streamlined the dispensing process as a whole, many community pharmacists reported facing errors or ambiguities in ePrescriptions requiring clarification during the dispensing process every week or even daily [15]. However, the results of this study indicate that pharmacy customers are not conscious of the rigidity of data systems or defects in ePrescriptions.

Many problems customers encountered during the pharmacy visit were related to their lack of awareness of the current status of their ePrescriptions such as the expiry date and to insufficient information received about the services. The consequences of these problems remain unknown, but they may have caused a gap in the customer's medication or at least a new visit to the pharmacy. Customers' difficulty keeping up to date with their ePrescribed medications has also been reported in our earlier studies among Finnish pharmacy staff and pharmacy customers $[37,38]$ as well as in studies conducted in the United States [22-24,39]. In Finland, the difficulty occurs particularly among 
older persons and medicine users without a computer, the Internet, or electronic IDs, which are required to log into the My Kanta service [37,38]. According to this study, most of the respondents check the status of their ePrescriptions by asking at the pharmacy, whereas the My Kanta service was used more rarely. In addition to inaccessibility, one reason why the Web service is relatively little used could be that customers are unaware of it [19]. Medicine users' familiarity with the Web service should be enhanced as eHealth services aim to improve patient empowerment. However, there will still be patients refusing or being unable to use new technologies. Future studies should examine which existing or new methods they prefer to receive information about their ePrescriptions.

Another finding suggesting pharmacy customers need assistance or additional information on ePrescription practices was that several respondents were unfamiliar with the patient instruction sheet. According to the Finnish Act on Electronic Prescriptions, the health care units involved are required to provide information about ePrescriptions and related services for patients before they receive an ePrescription for the first time [29]. However, laypeople probably need to be given information several times before they can adopt the new technology, which implies that the obligation to provide information should be extended from prescribers to dispensers. The information needs to be consistent and offered not only on the first occasion but repeatedly to new users of the ePrescription service. The health care professionals involved must also be properly trained in the new services in advance.

Some of the problems reported in renewing ePrescriptions and acting on behalf of someone else at the pharmacy may now be outdated because the system has undergone a few improvements since the survey was conducted. For one thing, patients have since been able to use the My Kanta service to send renewal requests by themselves. A phone number can be added to the request for a text message stating when a renewal has been authorized. Not only is the process convenient and streamlined but the electronic renewal of prescriptions via Web-based portals may also improve patients' medication adherence and the results of medication therapies [20,40,41]. Second, guardians are now entitled to view the ePrescriptions and other health records of their dependents less than 10 years in My Kanta. In the future, it would be sensible to allow patients to consent to another person acting on their behalf via the My Kanta service. The paperless system would ease the workload on pharmacies and health care units, which are required to archive consents for 12 years after they have expired. In addition, an electronic consent would be easier for the patient to cancel or change. To promote the use of My Kanta, a mobile app could be one of the future developments.

\section{Strengths and Limitations}

The findings of this study are based on a fully operational ePrescription system that had been in nationwide use for a few years during the survey. Most of the respondents had purchased medicines with an ePrescription several times before the study. The method used prevented us from sending out reminders but was suitable for reaching the target population, that is, persons with experiences of ePrescriptions. The response rate of $44 \%$ is comparable with that of other studies conducted with similar methods [42,43]. As the questionnaires were randomly distributed by pharmacists, we had no background information on the customers asked to participate in the study. Comparable statistics on Finnish pharmacy customers' characteristics are not available. However, the respondents' use of prescription medicines (regularly, temporarily, or both) as well as age and gender distributions were similar to those of an earlier study surveying Finnish pharmacy customers' experiences with generic substitution conducted with a similar method [42]. Consequently, we believe our study population well represents those customers purchasing their prescription medicines at Finnish community pharmacies.

This study explored Finnish pharmacy customers' first experiences with the recently implemented ePrescriptions in 2015. The nationwide system has been further developed ever since. To evaluate patients' adaptation to the ePrescription system more rigorously, their experiences, overall satisfaction, and ways of keeping up to date with their ePrescriptions should be continuously explored as the system matures. On the other hand, while the digital divide constantly narrows, future studies should investigate whether the new digital generation has different perspectives and ideas on how to make the ePrescription system more customer friendly.

\section{Conclusions}

Overall, Finnish pharmacy customers are highly satisfied with ePrescriptions and rarely have any problems with them. The problems encountered are often related to customers' unawareness of the practices and difficulty keeping up to date with the status of their ePrescriptions. Despite the national Web service for viewing ePrescriptions, customers' most common way of keeping up to date with their ePrescriptions is to ask at the pharmacy. In conclusion, pharmacy customers need clear information and assistance from health care professionals in advance and during implementation of a nationwide ePrescription system.

\section{Acknowledgments}

The authors are grateful to the pharmacies that distributed the questionnaire. The study was funded by The Social Insurance Institution of Finland (Kela). The opinions expressed in this document are those of the authors and do not reflect the official position of Kela.

\section{Conflicts of Interest}

None declared. 


\section{Multimedia Appendix 1}

The Questionnaire.

[PDF File (Adobe PDF File), 199KB-Multimedia Appendix 1]

\section{References}

1. Eysenbach G. What is e-health? J Med Internet Res 2001 Jun;3(2):E20 [FREE Full text] [doi: 10.2196/jmir.3.2.e20] [Medline: 11720962]

2. Kierkegaard P. E-prescription across Europe. Health Technol 2012 Dec 20;3(3):205-219. [doi: 10.1007/s12553-012-0037-0]

3. Gabriel MH, Swain M. Health IT. 2014. E-prescribing trends in the United States URL: https://www.healthit.gov/sites/ default/files/oncdatabriefe-prescribingincreases2014.pdf [accessed 2018-02-07] [WebCite Cache ID 6x3CFheYr]

4. Brennan J, McElligott A, Power N. National health models and the adoption of eHealth and ePrescribing in primary care-new evidence from Europe. J Innov Health Inform 2015 Nov 25;22(4):399-408. [doi: 10.14236/jhi.v22i4.97]

5. Government of Canada. Government of Canada: building a strong middle class URL: http://www.budget.gc.ca/2017/docs/ plan/chap-03-en.html [accessed 2018-02-07]

6. Health Information and Quality Authority. 2012 Nov. EPrescribing and Electronic Transfer of Prescriptions: an International Review URL: https://www.hiqa.ie/reports-and-publications/health-information/ eprescribing-and-electronic-transfer-prescriptions [accessed 2017-12-15] [WebCite Cache ID 6vj89083P]

7. Parv L, Kruus P, Mõtte K, Ross P. An evaluation of e-prescribing at a national level. Inform Health Soc Care 2016 Aug;41(1):78-95. [doi: 10.3109/17538157.2014.948170] [Medline: 25115948]

8. Timonen J, Heikkilä R, Ahonen R. Generic substitution in Finland: lessons learned during 2003-2008. J Pharm Health Serv Res 2013 May 24;4(3):165-172. [doi: 10.1111/jphs.12021]

9. Hellström L, Waern K, Montelius E, Astrand B, Rydberg T, Petersson G. Physicians' attitudes towards ePrescribing evaluation of a Swedish full-scale implementation. BMC Med Inform Decis Mak 2009 Aug 07;9:37 [FREE Full text] [doi: 10.1186/1472-6947-9-37] [Medline: 19664219]

10. Lapane KL, Rosen RK, Dubé C. Perceptions of e-prescribing efficiencies and inefficiencies in ambulatory care. Int J Med Inform 2011 Jan;80(1):39-46 [FREE Full text] [doi: 10.1016/j.ijmedinf.2010.10.018] [Medline: 21112243]

11. Odukoya OK, Chui MA. Relationship between e-prescriptions and community pharmacy workflow. J Am Pharm Assoc (2003) 2012 Nov;52(6):e168-e174 [FREE Full text] [doi: 10.1331/JAPhA.2012.12066] [Medline: 23229979]

12. Gagnon MP, Nsangou ÉR, Payne-Gagnon J, Grenier S, Sicotte C. Barriers and facilitators to implementing electronic prescription: a systematic review of user groups' perceptions. J Am Med Inform Assoc 2014 May;21(3):535-541 [FREE Full text] [doi: 10.1136/amiajnl-2013-002203] [Medline: 24130232]

13. Lapane KL, Waring ME, Dubé C, Schneider KL. E-prescribing and patient safety: results from a mixed method study. Am J Pharm Benefits 2011;3(2):e24-e34 [FREE Full text] [Medline: 24179595]

14. Kauppinen H, Ahonen R, Mäntyselkä P, Timonen J. Medication safety and the usability of electronic prescribing as perceived by physicians-a semistructured interview among primary health care physicians in Finland. J Eval Clin Pract 2017;23(6):1187-1194. [doi: 10.1111/jep.12759] [Medline: 28474487]

15. Kauppinen H, Ahonen R, Timonen J. The impact of electronic prescriptions on medication safety in Finnish community pharmacies: a survey of pharmacists. Int J Med Inform 2017 Apr;100:56-62. [doi: 10.1016/j.ijmedinf.2017.01.014] [Medline: 28241938]

16. Hammar T, Nyström S, Petersson G, Rydberg T, Åstrand B. Swedish pharmacists value ePrescribing: a survey of a nationwide implementation. J Pharm Health Serv Res 2010 Mar;1(1):23-32. [doi: 10.1211/jphsr.01.01.0012]

17. Hammar T, Nyström S, Petersson G, Rydberg T, Åstrand B. Patients satisfied with e-prescribing in Sweden: a survey of a nationwide implementation. J Pharm Health Serv Res 2011 Jun;2(2):97-105. [doi: 10.1111/j.1759-8893.2011.00040.x]

18. Montelius E, Astrand B, Hovstadius B, Petersson G. Individuals appreciate having their medication record on the web: a survey of attitudes to a national pharmacy register. J Med Internet Res 2008 Nov 11;10(4):e35 [FREE Full text] [doi: 10.2196/jmir.1022] [Medline: 19000978]

19. Lämsä E, Timonen J, Mäntyselkä P, Ahonen R. Pharmacy customers' experiences with the national online service for viewing electronic prescriptions in Finland. Int J Med Inform 2017 Jan;97:221-228. [doi: 10.1016/j.ijmedinf.2016.10.014] [Medline: 27919380]

20. McInnes DK, Shimada SL, Midboe AM, Nazi KM, Zhao S, Wu J, et al. Patient use of electronic prescription refill and secure messaging and its association with undetectable HIV viral load: a retrospective cohort study. J Med Internet Res 2017 Feb 15;19(2):e34 [FREE Full text] [doi: 10.2196/jmir.6932] [Medline: 28202428]

21. Traulsen JM, Almarsdóttir AB. Pharmaceutical policy and the lay public. Pharm World Sci 2005 Aug;27(4):273-277. [doi: 10.1007/s11096-005-8512-6] [Medline: 16228621]

22. Lapane KL, Dubé C, Schneider KL, Quilliam BJ. Patient perceptions regarding electronic prescriptions: is the geriatric patient ready? J Am Geriatr Soc 2007 Aug;55(8):1254-1259. [doi: 10.1111/j.1532-5415.2007.01248.x] [Medline: 17661966]

23. Duffy RL, Yiu SS, Molokhia E, Walker R, Perkins RA. Effects of electronic prescribing on the clinical practice of a family medicine residency. Fam Med 2010 May;42(5):358-363 [FREE Full text] [Medline: 20455110] 
24. Bergeron AR, Webb JR, Serper M, Federman AD, Shrank WH, Russell AL, et al. Impact of electronic prescribing on medication use in ambulatory care. Am J Manag Care 2013 Dec;19(12):1012-1017 [FREE Full text] [Medline: 24512036]

25. Cochran GL, Lander L, Morien M, Lomelin DE, Brittin J, Reker C, et al. Consumer opinions of health information exchange, e-prescribing, and personal health records. Perspect Health Inf Manag 2015;12:1e [FREE Full text] [Medline: 26604874]

26. Schleiden LJ, Odukoya OK, Chui MA. Older adults' perceptions of e-prescribing: impact on patient care. Perspect Health Inf Manag 2015;12:1d [FREE Full text] [Medline: 26807076]

27. Lau G, Ho J, Lin S, Yeoh K, Wan T, Hodgkinson M. Patient and clinician perspectives of an integrated electronic medication prescribing and dispensing system: a qualitative study at a multisite Australian hospital network. Health Inf Manag J 2017 Jan 01:1833358317720601. [doi: 10.1177/1833358317720601] [Medline: 28745564]

28. Porteous T, Bond C, Robertson R, Hannaford P, Reiter E. Electronic transfer of prescription-related information: comparing views of patients, general practitioners, and pharmacists. Br J Gen Pract 2003 Mar;53(488):204-209 [FREE Full text] [Medline: 14694696]

29. Finlex. Laki sähköisestä lääkemääräyksestä 61/2007 [The Law on Electronic Prescription] URL: http://www.finlex.fi/fi/ laki/ajantasa/2007/20070061 [accessed 2018-02-07] [WebCite Cache ID 6tfLeLINd]

30. Kanta Services. Prescripted and dispensed prescriptions per year URL: http://www.kanta.fi/documents/12105/4337108/ Resepti+vuosittain+en/63608a2e-a937-44ac-801d-b6e83ae292d8?t=1504604097000 [accessed 2018-02-07]

31. Association of Finnish Pharmacies. Pharmacies in numbers URL: http://www.apteekkariliitto.fi/apteekkitieto/ apteekit-numeroina [accessed 2017-09-22] [WebCite Cache ID 6tfCUTIvb]

32. Kanta Services. My Kanta pages URL: http://www.kanta.fi/omakanta [accessed 2017-11-10]

33. Kanta Services. Visiting Instructions URL: http://www.kanta.fi/asiointiohjeet [accessed 2017-11-10] [WebCite Cache ID 6urdTDDYK]

34. Finlex. Hallituksen esitys Eduskunnalle laiksi sähköisestä lääkemääräyksestä sekä laiksi lääkelain 57 ja 57 a §:n muuttamisesta 250/2006 URL: http://www.finlex.fi/fi/esitykset/he/2006/20060250.pdf [accessed 2018-02-07]

35. Hyppönen H, Hännikäinen K, Pajukoski M, Ruotsalainen P, Salmivalli L, Tenhunen E. Julkari.fi. 2006. Sähköisen reseptin pilotin arviointi II (2005-2006) [Evaluation of the National Electronic Prescribing Pilot II (2005-2006), with English summary] URL: http://www.julkari.fi/handle/10024/76598 [accessed 2017-11-10] [WebCite Cache ID 6urdgQeIQ]

36. Finnish Advisory Board on Research Integrity. Responsible conduct of research URL: http://www.tenk.fi/en/ responsible-conduct-of-research [accessed 2017-09-22] [WebCite Cache ID 6tfC77RnH]

37. Sääskilahti M, Ahonen R, Lämsä E, Timonen J. Sähköisen reseptin edut ja ongelmat - kyselytutkimus apteekkien asiakkaille [Benefits and problems of electronic prescriptions - a survey among pharmacy customers in Finland, with English summary]. Farmaseuttinen aikakauskirja Dosis 2016;32(2):129-141 [FREE Full text]

38. Timonen J, Kauppinen H, Ahonen R. Sähköisen reseptin ongelmat ja kehittämiskohteet - kyselytutkimus apteekkien farmaseuttiselle henkilöstölle [Problems and areas needing development in electronic prescriptions - A survey amongst community pharmacy staff, with English summary]. Suom Lääk 2016;71(3):152-159 [FREE Full text]

39. Frail CK, Kline M, Snyder ME. Patient perceptions of e-prescribing and its impact on their relationships with providers: a qualitative analysis. J Am Pharm Assoc (2003) 2014 Nov;54(6):630-633 [FREE Full text] [doi: 10.1331/JAPhA.2014.13176] [Medline: 25257842]

40. Sarkar U, Lyles CR, Parker MM, Allen J, Nguyen R, Moffet HH, et al. Use of the refill function through an online patient portal is associated with improved adherence to statins in an integrated health system. Med Care 2014 Mar;52(3):194-201 [FREE Full text] [doi: 10.1097/MLR.0000000000000069] [Medline: 24374412]

41. Lyles CR, Sarkar U, Schillinger D, Ralston JD, Allen JY, Nguyen R, et al. Refilling medications through an online patient portal: consistent improvements in adherence across racial/ethnic groups. J Am Med Inform Assoc 2016 Apr;23(e1):e28-e33 [FREE Full text] [doi: 10.1093/jamia/ocv126] [Medline: 26335983]

42. Heikkilä R, Mäntyselkä P, Hartikainen-Herranen K, Ahonen R. Customers' and physicians' opinions of and experiences with generic substitution during the first year in Finland. Health Policy 2007 Aug;82(3):366-374. [doi: 10.1016/j.healthpol.2006.10.006] [Medline: 17141355]

43. Tiihonen MJ, Heikkinen A, Ahonen RS. Do Finnish women using hormone replacement therapy need more information about risks. Pharm World Sci 2007 Dec;29(6):635-640. [doi: 10.1007/s11096-007-9115-1] [Medline: 17431814]
Abbreviations
eHealth: electronic health
ePrescriptions: electronic prescriptions 
Edited by G Eysenbach; submitted 10.11.17; peer-reviewed by D Volmer, S Lin; comments to author 06.12.17; revised version received 13.12.17; accepted 14.12.17; published 23.02.18

Please cite as:

Lämsä E, Timonen J, Ahonen R

Pharmacy Customers' Experiences With Electronic Prescriptions: Cross-Sectional Survey on Nationwide Implementation in Finland $J$ Med Internet Res 2018;20(2):e68

URL: http://www.jmir.org/2018/2/e68/

doi: 10.2196/jmir.9367

PMID: 29475826

CElina Lämsä, Johanna Timonen, Riitta Ahonen. Originally published in the Journal of Medical Internet Research (http://www.jmir.org), 23.02.2018. This is an open-access article distributed under the terms of the Creative Commons Attribution License (https://creativecommons.org/licenses/by/4.0/), which permits unrestricted use, distribution, and reproduction in any medium, provided the original work, first published in the Journal of Medical Internet Research, is properly cited. The complete bibliographic information, a link to the original publication on http://www.jmir.org/, as well as this copyright and license information must be included. 